\title{
Co mają wspólnego House of Cards i Machiavelli? O pożytkach $z$ wizualizacji problemu filozoficznego w nauczaniu historii idei
}

I. Nieraz uczestniczyłam w dyskusjach, podczas których utyskiwano na wypieranie kultury słowa pisanego przez bardziej egalitarną kulturę obrazkową. Co pewien czas słyszę wypowiedzi utrzymane albo w tonie sentymentalnym, albo wręcz zaprawione goryczą, że młodzi ludzie, którzy teraz rozpoczynają studia, nie mogą się równać pod względem erudycji ze studentami z poprzednich pokoleń - słowem: „młodzież już nie ta”. Nie jest moim celem, aby sądy te potwierdzać czy podawać w wątpliwość, ale - inaczej zdefiniować problem. Może warto byłoby przemyśleć to, jak twórczo wykorzystać narzędzia oferowane nam przez - tak często krytykowaną - popkulturę, by skutecznie przekazywać wiedzę studentom tu i teraz. Wszak to już Machiavelli nauczał, że na powodzenie nie może liczyć ani idealista tęsknie wpatrzony w ,złoty wiek” (niczym nauczyciel akademicki zestawiający teraźniejszość z przeszłością z korzyścią dla tej ostatniej), ani jednostka biernie poddająca się losowi (nauczyciel, który narzeka na studentów zamiast opracować nową strategię postępowania). Klucz do sukcesu - w tym przypadku dydaktycznego - spoczywa w rękach tych, którzy mając świadomość zmieniającej się rzeczywistości, realistycznie oceniają stan faktyczny, co więcej - przybierają wobec niego postawę aktywną i podejmują działanie, aby aktualną sytuację przekuć na swoją korzyść.

W moim artykule zastanawiam się nad możliwością zrobienia użytku z jednego z najbardziej reprezentatywnych elementów kultury popularnej, czyli seriali. W pierwszej części stawiam pytanie o wartość seriali jako takich w dydaktyce historii doktryn politycznych i prawnych. Nie ograniczam się jednak do refleksji czysto teoretycznej i dlatego w części drugiej omawiam, poparte własnym doświadczeniem dydaktycznym, studium przypadku - pokazuję, jak można posłużyć się amerykańskim serialem House of Cards, by przybliżyć studentom doktrynę N. Machiavellego. 
Pierwsza kwestia, na którą zamierzam zwrócić uwagę, odnosi się do relacji pomiędzy serialami a tradycyjnymi materiałami dydaktycznymi. Pragnę zaznaczyć, że udział seriali w dydaktyce przedmiotu wyobrażam sobie na prawach komplementarności. Antologia tekstów źródłowych i wybrane podręczniki nadal powinny stanowić dla studentów punkt wyjścia, co nie oznacza, że muszą być dla nich jedynym źródłem wiedzy o doktrynach. Seriale uważam za pomocne $\mathrm{w}$ procesie dydaktycznym przede wszystkim $\mathrm{z}$ uwagi na charakterystyczną dla nich kontekstualizację. Podczas lektury podręcznika czy tekstów źródłowych (należy przyznać, że do tych ostatnich sięgają nieliczni) studenci są najczęściej konfrontowani z wiedzą brzmiącą dla nich nazbyt abstrakcyjnie, a przez to często niezrozumiale. Dopóki nie wyposaży się w konkretną treść - taką, która przemawia do wyobraźni - wykładu o tym, jak dany myśliciel polityczny oceniał naturę ludzką czy co rozumiał pod pojęciem dobrze funkcjonującego państwa, dopóty większość uczestników ćwiczeń będzie traktować te zagadnienia jak niepowiązane ze sobą i wymagające bezmyślnego wyuczenia się litanie cudzych pomysłów.

Odmienność serialu wobec tradycyjnych materiałów dydaktycznych polega na wizualizacji problemu filozoficznego, który przybiera postać określonej historii, umieszczonej w sprecyzowanym kontekście. Uważam, że można zrobić właściwy użytek z tej konkretności serialu, tzn. uznać wybraną scenę za egzemplifikację, zarysowanego w podręczniku w sposób ogólny, zjawiska czy mechanizmu politycznego. Odwołanie się do plastycznego przykładu, powinno pomóc w zapamiętaniu omawianej tematyki - w głównej mierze dzięki temu, że przedstawiono ją w sposób zrozumiały. Myślę, że szczególnie pozytywny wpływ na poziom zrozumienia zagadnienia ma udział studentów w dyskusji o serialu, a o tym z kolei decyduje stopień zainteresowania daną problematyką. Dodatkowo procesowi zapamiętywania z wykorzystaniem serialu towarzyszy jeszcze jeden czynnik - chodzi o uczenie się wspomagane przez emocje. Lektura podręcznika akademickiego czy tekstu traktatu filozoficznego zazwyczaj nie jest w stanie dostarczyć odbiorcy przeżyć porównywalnych z tymi, które stają się jego udziałem, gdy utożsamia się z losami serialowego bohatera. Argument ten wywodzę z obserwacji samych studentów w trakcie zajęć. Sposób, jak i treść wypowiedzi moich rozmówców świadczą o tym, że poczynania głównego bohatera House of Cards wzbudziły w nich szereg emocji (od fascynacji strategicznym geniuszem Franka Underwooda, przez odrazę łatwością, z jaką eliminował przeciwników politycznych, po śmiech, kiedy Underwood zwracał się bezpośrednio do widza - przebicie czwartej ściany - by skomentować aktualną sytuację). Stawiam hipotezę, że w tym przypadku odczuwane emocje pozytywnie wpływają na stopień zapamiętania dyskutowanych w kontekście serialu zagadnień doktrynalnych. Jeżeli nawet w tekstach źródłowych występują przykłady, poprzez które filozof ilustruje własne poglądy, to $\mathrm{z}$ oczywistych względów mają one charakter hi- 
storyczny. Tym samym pomimo opisu zjawisk niewątpliwie konkretnych, interpretowane są przez studentów jako pozbawione związku z ich doświadczeniami. Poprzez seriale i zawarty w nich aktualny kontekst - staje się możliwe ukazanie uniwersalności przynajmniej części zagadnień, którymi zajmowali się myśliciele polityczni.

Historia doktryn politycznych i prawnych wyróżnia się interdyscyplinarnością. Jeżeli za jedyne materiały dydaktyczne miałyby nam służyć podręcznik i teksty źródłowe - kwestionowałoby to wiarygodność poprzedniej deklaracji. Dopiero odsłonięcie związków naszego przedmiotu z literaturą piękną, malarstwem, architekturą czy serialami (filmami) uświadamia, na czym owa interdyscyplinarność polega, jak silny był i jest wpływ idei politycznych na tak rozmaite dziedziny ludzkiej aktywności. Tym samym włączenie seriali do dydaktyki historii doktryn na swój sposób przyczynia się do rzeczywistego rozwoju przedmiotu w aspekcie interdyscyplinarności.

II. Uczestniczący w moich zajęciach studenci otrzymują ze stosownym wyprzedzeniem zadanie - są proszeni o przeczytanie Księcia oraz obejrzenie wybranych scen z serialu House of Cards, tzn. takich, które można zinterpretować według klucza doktrynalnego. Zatem, zgodnie z wcześniejszą uwagą, serial ma być jedynie narzędziem ilustrującym treść oryginalnego tekstu i pomagającym w jego lepszym zrozumieniu. Jeżeli studenci sumiennie przyłożyli się do pracy (zarówno przeczytali książkę, jak i obejrzeli House of Cards), to $\mathrm{w}$ istocie jeszcze przed zajęciami poświęconymi Machiavellemu mają szansę dodatkowo utrwalić wiedzę; skoro wiedzieli, że serial będzie przedmiotem dyskusji na ćwiczeniach, przystępując do jego oglądania towarzyszy im określona intencja - konieczność wydobycia ze scen serialu machiavellowskich wątków. Jest to odmienny sposób oglądania serialu od tego, do którego większość z nich przywykła - zamiast ukierunkowywać wyłącznie na rozrywkę, wymaga od nich skupienia i krytycyzmu.

Oglądaniu przeze mnie serialu House of Cards, którego pierwszy sezon miał premierę w 2013 roku, towarzyszyło zaskoczenie wielością wątków wykazujących istotne podobieństwa z doktryną N. Machiavellego wyłożoną w Księciu; można wręcz odnieść wrażenie, że zamysłem twórców serialu było stworzenie, osadzonej we współczesności, adaptacji dzieła renesansowego twórcy. Serialowy „książę” to Francis Underwood - whip z prezydenckimi ambicjami. Towarzyszy mu żona - Claire - również niepozbawiona ambicji bizneswoman. Można ją określić damskim wcieleniem „księcia” - podobnie jak małżonek perfekcyjnie opanowała i stosuje w praktyce zalecenia florenckiego myśliciela. Dydaktyczna wartość House of Cards polega moim zdaniem na tym, że serial umożliwia rekonstrukcję siatki pojęć konstytuujących doktrynę Machiavellego (realizm, virtù, fortuna, occasione, necessità) $i$ - co nie mniej istotne - pozwala tchnąć w nie nowe życie. W dalszej części artykułu 
omówię kilka spośród serialowych scen, które wspólnie ze studentami interpretujemy na zajęciach, by nie tylko odnaleźć w nich punkty wspólne z nauką Machiavellego o rządzeniu, ale uświadomić sobie ciągłą aktualność tego programu politycznego z początku XVI stulecia.

Ilustracją konfrontacji pomiędzy stanowiskiem realistycznym $\mathrm{i}$ idealistycznym jest rozmowa serialowego bohatera z szefową sztabu prezydenta. Linda Vasquez, komunikując $\mathrm{w}$ imieniu prezydenta ${ }^{1}$ konieczność pozostania przez Franka na stanowisku whipa ,zmianą okoliczności”, uzasadnia odstąpienie od obietnicy wyborczej (realizm), z czym Underwood próbuje polemizować argumentem z ducha idealistycznym: „Natura obietnic jest taka, Lindo, że są na to odporne" 2 . Gdy po zwycięstwie odniesionym w wyborach prezydenckich przez Garetta Walkera - kandydata cieszącego się przez całą kampanię poparciem ze strony Francisa Underwooda, ten ostatni nie otrzymuje obiecanego stanowiska sekretarza stanu, jego żona czyni mu zarzuty z powodu nie dość realistycznej oceny intencji współpracowników politycznych: „zazwyczaj nie masz problemu z niedocenianiem ludzi" ". Paradoksalnie lojalność Franka zostaje... ukarana. Wypowiedź Claire - żony Franka - o „niedocenieniu ludzi” jest rzecz jasna ironiczna, bowiem jak nauczał Machiavelli z natury ludzie „(...) są niewdzięczni, zmienni, kłamliwi”4; pewność Underwooda co do realizacji złożonej mu przez przyszłego prezydenta obietnicy osłabiła jego zwyczajową czujność i nieufność. Te początkowe sceny wystarczają, by dostrzec związki z dwoma kluczowymi zagadnieniami z doktryny Machiavellego - po pierwsze chodzi o sformułowane przez myśliciela zalecenie, aby wyzbyć się skłonności do idealizowania rzeczywistości, czyli widzenia świata takim, jakim chcielibyśmy go widzieć, po drugie zaś o pesymistyczną wizję natury ludzkiej. Dalszy rozwój akcji serialu świadczy o niepodzielnej dominacji orientacji realistycznej w postępowaniu głównego bohatera.

Jedno z oblicz realizmu Franka to - oparta wyłącznie na faktach - posiadana przez niego wiedza na temat: stałych cech ludzkiego charakteru ${ }^{5}$, aktualnej diagnozy sytuacji politycznej ${ }^{6}$, ludzkich słabości (pieczołowicie gromadzone - z pomocą wiernego Douga Stampera - informacje, które w zależności od kontekstu mają w przyszłości posłużyć albo kompromitacji, albo

${ }^{1}$ Widoczne nawiązanie do Machiavellego, który radził, aby książę korzystał z pomocy pośredników w przekazywaniu złych nowin.

${ }^{2}$ House of Cards, sezon I, odc. 1.

3 Ibidem.

${ }^{4}$ N. Machiavelli, Książę, thum. Cz. Nanke, Kęty 2005, s. 68.

5 „Musisz zrozumieć, że południowcy to szlachetni ludzie. Pokora to forma ich dumy - jest jednocześnie ich siłą i słabością. Wystarczy, że się przed nimi ukorzysz, a wówczas zrobią wszystko, o co poprosisz", House of Cards, sezon I, odc. 3.

6 „David Rasmussen jest liderem większości, więc jest o krok przede mną i krok za Birchem, co można porównać do bycia między głodnym wilkiem a buńczuczną owieczką. Zobaczymy czy zostanie ze stadem, czy dołączy do wilków”, ibidem, odc. 4. 
zastraszeniu danego polityka), a także atutów, na podstawie których dobiera sobie współpracowników (np. w Lindzie docenia to, że jest „twarda niczym skała", a Jackie Sharp ceni za bezwzględny pragmatyzm i „czystą historię” - z podziwem, a może i odrobiną żalu stwierdza, że nawet jemu nie udało się znaleźć na nią żadnego haka). Realizm Underwooda nie sprowadza się jedynie do warstwy psychologicznej oceny ludzkich dyspozycji, ale - podobnie jak w Księciu - stanowi swoistego ducha przenikającego całość poczynań polityka.

Starając się uchwycić istotę sformułowanej przez Machiavellego krytyki księcia-doktrynera, wystarczy przyjrzeć się relacji Underwooda z ekspertem ds. edukacji, Donaldem Blythem. Ten ostatni z niejaką ulgą reaguje na wiadomość o przecieku (jego kontrowersyjny projekt reformy szkolnictwa wymagałby znacznego podwyższenia podatków, co stałoby w sprzeczności z linią ideową nowo wybranego prezydenta), argumentując, że: ,przynajmniej ludzie poznali jego poglądy" twa o skuteczności głównego bohatera zadecydowała m.in. jego świadomość władzy, jaką dają media (to Frank przekazuje zaprzyjaźnionej dziennikarce pierwszą, radykalną wersję projektu, a jednocześnie dba o to, aby odpowiedzialność za przeciek przypisano Blythe'owi) - polityk zdaje sobie sprawę, że uwaga mediów skupi się na programowej niezgodności planowanej reformy z dotychczasowym stanowiskiem prezydenta; liczy się pierwsze wrażenie, jakie wywołał projekt, tj. zaplanowane przez Franka i uzyskane z wykorzystaniem mediów straty wizerunkowe poniesione przez prezydenta ${ }^{9}$. W realizacji kolejnego etapu swojego planu - nakłonienie Blythe'a do dobrowolnej rezygnacji i co więcej otrzymanie od niego propozycji zastąpienia go w pracach nad reformą - Underwood posługuje się wiedzą na temat cech charakteru Blythe' ${ }^{10}$ oraz jego przywiązania do poglądów. „Naprzód! - tak brzmi okrzyk bojowy. Zostaw ideologię niedoszłym przywódcom. Mnie ona na nic"11 - komentuje Frank, obnażając słabości polityki zorientowanej na wierność konkretnej doktrynie, bo ta hamuje niezbędną skutecznemu władcy elastyczność w adaptacji do zmiennych okoliczności.

Przykład innego rodzaju serialowego starcia pomiędzy realizmem a idealizmem (tu rozumianym jako dążenie do prawdy) stanowi zebranie z udziałem Underwooda i władz Gaffney, w trakcie którego zastanawiano się nad

7 Ibidem, odc. 1.

${ }^{8}$ Ibidem, odc. 2.

9 Nie ma znaczenia początkowy etap prac nad reformą - liczy się to, jak mówi Underwood, że: „Nie można drugi raz zrobić pierwszego wrażenia”, ibidem.

10 „Męczennik najbardziej na świecie pragnie miecza, na który może upaść. Trzeba go dobrze naostrzyć, przytrzymać pod odpowiednim kątem i trzy, dwa, jeden...”. W rozmowie z Frankiem Blythe przyznaje się, że pewnie czuje się tylko w polityce resortowej, zaś wielka polityka onieśmiela go, bo - jak stwierdza - nie jest „typem rozdającego karty”, ibidem.

${ }^{11}$ Ibidem. 
rozwiązaniem konfliktu pomiędzy władzami miasteczka a rodzicami nastolatki zmarłej w wyniku wypadku (groźba pozwu przeciwko miastu). Uczestnicy spotkania podzielili się na zwolenników procesu sądowego i tych, którzy opowiadają się za ugodą. Pierwsi odrzucają możliwość pójścia na ugodę, bo w ich przekonaniu oznaczałoby to przyznanie się miejscowych władz do winy za śmierć dziewczyny: „(...) na szali jest zasada”12. Wyrazicielem poglądów przeciwników procesu jest Frank Underwood - w tym przypadku jego realizm nie ma nic wspólnego z pragnieniem rekonstrukcji prawdziwego przebiegu wydarzeń, lecz zmierza ku skutecznemu (szybkiemu) zakończeniu sporu: „Kiedy Orrin przekona ławników, żeby wypłakali morze łez, kiedy Gaffney się «przekręci», bo nie będziecie mogli zapłacić siedmiocyfrowego odszkodowania, kiedy wylecicie z roboty, a ja przegram wybory - wtedy możesz zrzędzić mi o zasadach, bo czasu będziemy mieć w bród"13; jego realizm to synonim pragmatyzmu.

Doznana przez Underwooda porażka - brak nominacji na sekretarza sta$\mathrm{nu}$ - staje się dla polityka punktem wyjścia do opracowania nowej strategii zdobycia władzy w państwie przy jednoczesnym utrzymaniu pozorów ścisłej współpracy z dotychczasowym obozem politycznym. W moim przekonaniu Underwooda można zestawić z ,nowym księciem"14 Machiavellego, który panowanie zawdzięcza nie zbiegowi okoliczności, dziedziczeniu tronu czy wyborom, lecz własnej virtù. Zresztą w konsekwentnym realizowaniu programu przejęcia władzy Machiavelli upatrywał gwarancji stabilnych rządów władzę przejmuje człowiek „wypróbowany”, tj. zmuszony przejść liczne próby, torując sobie drogę do politycznego zwycięstwa. Bohater House of Cards nie ukrywa, że „do królowania nie brakuje mu niczego prócz królestwa”, kiedy w pogardliwy sposób porównuje zajmowane przez siebie stanowisko do pracy hydraulika ${ }^{16}$ albo gdy podczas rozmowy Zoe Barnes - dziennikarka proponująca mu współpracę (Underwood ma zostać jej źródłem informacji) - podkreśla, że coś ich łączy: poczucie niedocenienia i przekonania, że oboje stać na więcej; redakcja gazety, w której pracuje Zoe, zleca jej pisanie artykułów poświęconych mało znaczącym zagadnieniom lokalnym, podczas gdy ta ambitna dziennikarka chciałaby zajmować się polityką. Frank udowadnia, że nie brakuje mu cech pożądanych dla księcia: umiejętnie dostosowuje się do zmieniających się okoliczności (z twarzą pokerzysty zapewnia szefową sztabu prezydenta o uszanowaniu decyzji głowy państwa i wręcz chwali wybór kandydata na stanowisko, które jeszcze przed chwilą sam spodziewał się otrzy-

12 Ibidem, odc. 3 .

13 Ibidem.

14 Por. N. Machiavelli, op. cit., s. 40-43.

15 Ibidem, s. 43.

16 „Przeczyszczam rury, by nie zapchały się szlamem. Ale kończę z pracą hydraulika. Poparłem właściwą osobę: coś za coś”, ibidem, odc. 1. 
mać), potrafi dostrzec pozytywne strony przegranej (w rozmowie z bliskim współpracownikiem, Dougiem Stamperem, zwraca uwagę, że od tej chwili zyskali niezależność: „Nikomu już nie służymy”17) i czyni z początkowej porażki zalążek przyszłego sukcesu: „Tak się pożera wieloryba - kawałek po kawałku"18 (kontrola nad ustawą edukacyjną, kompromitacja Michaela Kerna - prezydenckiego kandydata na sekretarza stanu i doprowadzenie do nominacji Catherine Durant, zadbanie o powierzenie innych wpływowych stanowisk politykom lojalnym wobec Underwooda - to tylko niektóre z etapów owej strategii stopniowego ,pożerania wieloryba”, obliczonej na ostateczne zdobycie władzy w państwie).

O faktycznej jakości virtù polityka świadczy sposób reagowania na wydarzenia składające się na jego środowisko polityczne, tj. na fortunę, occasione i necessità. Frank należy do osób, które nie dość, że - zgodnie z zaleceniem Machiavellego - przyjmują aktywną postawę wobec $\operatorname{losu}^{19}$ to jeszcze czynią coś więcej - kreują przyszłość, np. kiedy napisany pod wpływem Underwooda artykuł o kandydaturze Durant inicjuje szum medialny skutkujący tym, że ostatecznie prezydent nominuje Durant na sekretarz stanu, zaczynają się spełniać słowa Franka skierowane do dziennikarki, Zoe Barnes: „Razem dokonamy dzieła stworzenia"20. Jest przewidujący i odznacza się przenikliwością polityczną - przypomina to wyciągnięcie wniosków z nauki Machiavellego o reagowaniu na chorobę we wczesnym i późnym stadium ${ }^{21}$ - udaje się do rodzimego okręgu wyborczego, by jak najszybciej zażegnać konflikt (ugoda z rodziną zmarłej). Niczym Machiavellowski książę, Underwood słucha rad mądrego i godnego zaufania doradcy ${ }^{22}$ - Douga Stampera, który uświadamia mu potencjalne następstwa (z niebezpieczeństwem utraty stanowiska w Kongresie włącznie) zlekceważenia całej sytuacji poprzez potraktowanie jej jako błahego problemu o lokalnym zasięgu. Frankowi jako wytrawnemu psychologowi udaje się - pomimo początkowych trudności - nawiązać kontakt z rodzicami zmarłej nastolatki i przekonać ich do zawarcia ugody. Wykorzystuje w tym celu religię - dowiaduje się, że są oni osobami głęboko wierzącymi, i dzięki pomocy zaprzyjaźnionego pastora Frank zabiera głos podczas niedzielnego nabożeństwa, zwracając się do zgromadzonych z żarliwym apelem utrzymanym w konwencji kazania. Tym samym Underwood znajduje sposób na wzbudzenie zaufania w rodzicach przeżywających żałobę, ponieważ posługuje się bliskim im językiem religijnym. To z kolei wyraźny przykład zalecanego przez Machiavellego używania religii niczym narzędzia służącego

\footnotetext{
17 Ibidem, odc. 1.

18 Ibidem.

19 Por. N. Machiavelli, op. cit., s. 89.

20 House of Cards, sezon I, odc. 2.

21 Por. N. Machiavelli, op. cit., s. 35.

22 Por. ibidem, s. 83-86.
} 
realizacji określonych celów politycznych oraz stwarzania przez księcia pozorów pobożności jako istotnego elementu kreowania wizerunku ${ }^{23}$.

Underwood umiejętnie rozpoznaje occasione i robi z nich użytek, np. zgadzając się na układ proponowany przez dziennikarkę Zoe Barnes, zyskuje dzięki temu skuteczny środek oddziaływania na opinię publiczną; Frank ma bowiem świadomość, że współcześnie o powodzeniu polityka decyduje nie tylko psychologiczna wiedza o naturze ludzkiej, ale również kontrola nad mediami. Inny przykład occasione polega na interwencji Underwooda w sprawie uwolnienia $\mathrm{z}$ aresztu kongresmena Petera Russo. Pomoc udzielona politykowi to nie akt altruizmu, lecz sposób na całkowite uzależnienie go od Franka (groźba upublicznienia informacji o prowadzeniu samochodu pod wpływem alkoholu, narkotyków i w towarzystwie prostytutki), a tym samym uczynienie z Russo marionetki w politycznej grze, w której karty rozdaje Underwood.

Już pierwsza scena serialu świadczy o wniknięciu przez głównego bohatera w istotę necessità - uśmiercenie dogorywającego psa polityk poprzedza komentarzem: „Takie sytuacje wymagają kogoś, kto zrobi coś nieprzyjemnego, ale koniecznego" 24 . Cel w postaci zdobycia władzy najpierw wiceprezydenta, a w końcu prezydenta USA, uzasadnia - zdaniem Franka - posługiwanie się kłamstwem (fałszywe przypisanie autorstwa propalestyńskiego artykułu prezydenckiemu kandydatowi na sekretarza stanu, co w efekcie skutkuje wycofaniem nominacji czy prowokacja z wrzuceniem cegły do domu Underwoodów po to, by doprowadzić do zakończenia strajku nauczycieli), a nawet zbrodnią (z chwilą, gdy zarówno Russo, jak i Zoe zaczynają grozić ujawnieniem informacji dyskredytujących Underwooda, a przez to odbierających mu szansę na urzeczywistnienie jego prezydenckich planów - polityk za konieczne uznaje zabicie oboje).

III. Z moich obserwacji wynika, że w zajęcia poprzedzone oglądaniem serialu House of Cards było zaangażowanych zdecydowanie więcej studentów niż zazwyczaj - w dyskusji uczestniczyły nie tylko osoby zawsze aktywne, ale także te, które do tej pory milczały lub w niewielkim stopniu zaznaczyły swój udział w ćwiczeniach. Moim zdaniem jednoznacznie wynikało to z uzupełnienia tradycyjnych materiałów dydaktycznych o serial. Potwierdzały to wypowiedzi studentów, którzy w trakcie zajęć podkreślali z jednej strony atrakcyjność serialu (interesująca ich tematyka oraz emocjonująca forma przekazu), z drugiej zaś - chętnie odszukiwali analogie pomiędzy doktryną Księcia a scenami z House of Cards. Prowadzone przez studentów spory, o to czy daną sytuację z serialu można zakwalifikować do kategorii occasione czy może raczej necessità, oprócz tego, że dostarczają satysfakcji nauczycielowi -

${ }^{23}$ Por. ibidem, s. 69-71.

${ }^{24}$ House of Cards, sezon I, odc. 1. 
to przede wszystkim umożliwiają studentom sprawdzenie w oparciu o współczesny materiał empiryczny (serial) poziomu zrozumienia założeń wybranej doktryny. Tym samym przynajmniej część z nich przestaje utożsamiać historię doktryn politycznych i prawnych z przedmiotem wymagającym od nich opanowania określonego zasobu wiedzy pamięciowej i dostrzega w nim swego rodzaju warsztaty pomagające rozwinąć takie kompetencje, jak: krytyczne myślenie, analiza sytuacji z perspektywy odmiennych stanowisk doktrynalnych czy sztuka argumentacji. Myślę, że cenną informacją jest dla uczestników tego rodzaju zajęć to, że serial - powszechnie kojarzony z rozrywką czy wręcz z nałogiem (binge-watching jako kompulsywne oglądanie kilku odcinków czy wręcz całego sezonu na raz) - może posłużyć jako przedmiot badań naukowych.

\section{WHAT DO THE HOUSE OF CARDS AND MACHIAVELLI HAVE IN COMMON? ON THE BENEFITS OF VISUALISING A PHILOSOPHICAL PROBLEM IN THE TEACHING OF THE HISTORY OF POLITICAL IDEAS}

\section{Summary}

The aim of this paper is to prove that a good academic teacher exhibits similar characteristics to those of the Machiavelli's prince. In the same way as the latter who, instead of longing for the idealized past or pointlessly criticizing the present, would simply decide to adapt to the changing circumstances, the former, set in an academic context, might approach the creative adaptation to changes as, for example, the turning to a TV series as a helping tool in the teaching of the history of political ideas.

In the first part of the paper, issues such as: the relationships between TV series and traditional teaching materials, or the explanatory function of TV series and their relation to the interdisciplinary nature of the history of political ideas are analyzed. The second part of the paper is a case study. Based on her didactic experience, the authoress proposes a way in which a teacher can use the House of Cards TV series to familiarize students with the most important political ideas of The Prince. 


\section{QUELS POINTS EN COMMUN PEUT-ON TROUVER ENTRE LA SÉRIE TÉLÉVISÉE HOUSE OF CARDS ET MACHIAVELLI? SUR L'UTILITÉ DE LA VISUALISATION DU PROBLÈME PHILOSOPHIQUE DANS L'ENSEIGNEMENT DE L'HISTOIRE DES IDÉES}

\section{Résumé}

L'article vise à démontrer qu'un bon didactitien, à l'instar d'ailleurs un peu de l'efficace Prince de N. Machiavelli, ne perd pas son temps ni pour la nostalgie des temps passés idéalisés, ni pour la critique improductive du présent, mais il entreprend des actions afin de s'adapter aux circonstances changeantes. L'adaptation créative aux changements consiste, en l'occurrence, en la proposition de réfléchir sur l'exploitation des séries télévisées dans l'enseignement de l'histoire des doctrines politiques et juridiques. Dans la première partie de la présente publication, l'auteur présente quelquesunes de ses réflexions telles que le rapport entre les séries télévisées et les supports didactiques traditionnels, la fonction explicative des séries télé ou encore leur lien avec l'aspect interdisciplinaire de la matière. La deuxième partie se concentre par contre sur une sorte d'étude de cas où, m'appuyant sur ma propre expérience didactique, je démontre comment il est possible de se servir de la série télévisée House of Cards afin de familiariser les étudiants avec la grille des notions les plus importantes constituant la doctrine de Machiavelli, développée dans son traité le Prince. 